This paper was prepared for the Homer Jones Lecture, Federal Reserve Bank of St. Louis, March 30, 2000. Frederic S. Mishkin is a professor at the Graduate School of Business, Columbia University and a scholar at the National Bureau of Economic Research. He thanks Dan Thornton, Bill Poole, Lars Svensson, and the participants in the Macro Lunch at Columbia University for their helpful comments. Any views expressed in this paper are those of the author only and not those of Columbia University or the National Bureau of Economic Research.

\section{What Should Central Banks Do?}

\author{
Frederic S. Mishkin
}

\section{INTRODUCTION}

$\mathrm{n}$ the last twenty years, there has been substantial rethinking about how central banks should do their job. This rethinking has led to major changes in how central banks operate, and we are now in an era in which central banks in many countries throughout the world have had notable success-keeping inflation low, while their economies experience rapid economic growth. In this lecture, I outline what we think we have learned about how central banks should be set up to conduct monetary policy and then apply these lessons to see if there is room for institutional improvement in the way the Federal Reserve operates.

The lecture begins by discussing seven guiding principles for central banks and then uses these principles to outline what the role of central banks should be. This framework is then used to see how the institutional features of the Fed measure up. I will take the view that despite the Fed's extraordinarily successful performance in recent years, we should not be complacent. Changes in the way the Fed is set up to conduct its business may be needed to help ensure that the Fed continues to be as successful in the future.

\section{GUIDING PRINCIPLES FOR CENTRAL BANKS}

Recent theorizing in monetary economics suggests seven basic principles that can serve as useful guides for central banks to help them achieve successful outcomes in their conduct of monetary policy. These are:

- Price stability provides substantial benefits;

- Fiscal policy should be aligned with monetary policy;

- Time inconsistency is a serious problem to be avoided;
- Monetary policy should be forward looking;

- Accountability is a basic principle of democracy;

- Monetary policy should be concerned about output as well as price fluctuations; and

- The most serious economic downturns are associated with financial instability.

We will look at each of these principles in turn.

\section{Price Stability Provides Substantial Benefits to the Economy}

In recent years a growing consensus has emerged that price stability - a low and stable inflation rateprovides substantial benefits to the economy. Price stability prevents overinvestment in the financial sector, which in a high-inflation environment expands to profitably act as a middleman to help individuals and businesses escape some of the costs of inflation. ${ }^{1}$ Price stability lowers the uncertainty about relative prices and the future price level, making it easier for firms and individuals to make appropriate decisions, thereby increasing economic efficiency. ${ }^{2}$ Price stability also lowers the distortions from the interaction of the tax system and inflation. ${ }^{3}$

All of these benefits of price stability suggest that low and stable inflation can increase the level of resources productively employed in the economy, and might even help increase the rate of economic growth. While time-series studies of individual countries and cross-national comparisons of growth rates are not in total agreement, there is a consensus that inflation is detrimental to economic growth, particularly when inflation is at high levels. ${ }^{4}$ Therefore, both theory and evidence suggest that monetary policy should focus on promoting price stability.

\section{Align Fiscal Policy with Monetary Policy}

One lesson from the "unpleasant monetarist arithmetic" discussed in Sargent and Wallace (1981)

\footnotetext{
${ }^{1}$ E.g., see English (1996).

2 E.g., see Briault (1995).

3 E.g., see Fischer (1994) and Feldstein (1997).

${ }^{4}$ See the survey in Andersen and Gruen (1995).
} 
and the recent literature on fiscal theories of the price level (Woodford, 1994 and 1995) is that irresponsible fiscal policy may make it more difficult for the monetary authorities to pursue price stability. Large government deficits may put pressure on the monetary authorities to monetize the debt, thereby producing rapid money growth and inflation. Restraining the fiscal authorities from engaging in excessive deficit financing thus aligns fiscal policy with monetary policy and makes it easier for the monetary authorities to keep inflation under control.

\section{Time Inconsistency Is a Serious Problem To Be Avoided}

One of the key problems facing monetary policymakers is the time-inconsistency problem described by Calvo (1978), Kydland and Prescott (1977), and Barro and Gordon (1983). The time-inconsistency problem arises because there are incentives for a policymaker to try to exploit the short-run tradeoff between employment and inflation to pursue shortrun employment objectives, even though the result is poor long-run outcomes. Expansionary monetary policy will produce higher growth and employment in the short-run. Therefore, policymakers will be tempted to pursue this policy even though it will not produce higher growth and employment in the long-run because economic agents adjust their wage and price expectations upward to reflect the expansionary policy. Unfortunately, however, expansionary monetary policy will lead to higher inflation in the long-run, with its negative consequences for the economy.

McCallum (1995) points out that the time-inconsistency problem by itself does not imply that a central bank will pursue expansionary monetary policy that leads to inflation. Simply by recognizing the problem that forward-looking expectations in the wage- and price-setting process promotes a strategy of pursuing expansionary monetary policy, central banks can decide not to play that game. From my first-hand experience as a central banker, I can testify that central bankers are very aware of the time-inconsistency problem and are, indeed, extremely averse to falling into a time-inconsistency trap. However, even if central bankers recognize the problem, there still will be pressures on the central bank to pursue overly expansionary monetary policy by politicians. Thus, overly expansionary monetary policy and inflation may result, so that the time-inconsistency problem remains. The time-inconsistency problem is just shifted back one step; its source is not in the central bank, but rather, resides in the political process.

The time-inconsistency literature points out both why there will be pressures on central banks to pursue overly expansionary monetary policy and why central banks whose commitment to price stability is in doubt are more likely to experience higher inflation. In order to prevent high inflation and the pursuit of a suboptimal monetary policy, monetary policy institutions need to be designed in order to avoid the time-inconsistency trap.

\section{Monetary Policy Should Be Forward Looking}

The existence of long lags from monetary policy actions to their intended effects on output and inflation suggests that monetary policy should be forward looking. If policymakers wait until undesirable outcomes on inflation and output fluctuations actually arise, their policy actions are likely to be counterproductive. For example, by waiting until inflation has already appeared before tightening monetary policy, the monetary authorities will be too late; inflation expectations will already be embedded into the wage- and price-setting process, creating an inflation momentum that will be hard to contain. Once the inflation process has gotten rolling, the process of stopping it will be slower and costlier. Similarly, by waiting until the economy is already in recession, expansionary policy may kick in well after the economy has recovered, thus promoting unnecessary output fluctuations and possible inflation.

To avoid these problems, monetary authorities must behave in a forward-looking fashion and act preemptively. For example, assume that it takes two years for monetary policy to have a significant effect on inflation. Under these circumstances, even if inflation is quiescent currently (with an unchanged stance of monetary policy) and policymakers forecast inflation to rise in two years time, they must act immediately to head off the inflationary surge.

\section{Policymakers Should Be Accountable}

A basic principle of democracy is that the public should have the right to control the actions of the government: In other and more famous words, "The government should be of the people, by the people and for the people." Thus, the public in a democracy must have the capability to "throw the bums out" or punish incompetent policymakers 
through other methods in order to control their actions. If policymakers cannot be removed from office or punished in some other way, this basic principle of democracy is violated. In a democracy, government policymakers need to be held accountable to the public.

A second reason why accountability of policymakers is important is that it helps to promote efficiency in government. Making policymakers subject to punishment makes it more likely that incompetent policymakers will be replaced by competent ones and creates better incentives for policymakers to do their jobs well. Knowing that they are subject to punishment when performance is poor, policymakers will strive to get policy right. If policymakers are able to avoid accountability, then their incentives to do a good job drop appreciably, making poor policy outcomes more likely.

\section{Monetary Policy Should Be Concerned with Output as well as Price Fluctuations}

Price stability is a means to an end-a healthy economy - and should not be treated as an end in itself. Thus, central bankers should not be obsessed with inflation control and become what Mervyn King (1997) has characterized as "inflation nutters." Clearly, the public cares about output as well as inflation fluctuations, and so the objectives for a central bank in the context of a long-run strategy should not only include minimizing inflation fluctuations, but should also include minimizing output fluctuations. Objective functions with these characteristics have now become standard in the monetary economics literature, which focuses on the conduct of monetary policy (e.g., see the papers in Taylor, 1999).

\section{The Most Serious Economic Downturns Are Associated with Financial Instability}

A reading of U.S. monetary history (Friedman and Schwartz, 1963, Bernanke, 1983, and Mishkin, 1991) indicates that the most serious economic contractions in U.S. history, including the Great Depression, have all been associated with financial instability. Indeed, this literature suggests that financial instability is a key reason for the depth of these economic contractions. The recent financial crises and depressions in Mexico and East Asia also support this view (Mishkin, 1996, 1999a and Corsetti, Pesenti, and Roubini, 1998). Preventing financial instability is, therefore, crucial to promoting a healthy economy and reducing output fluctuations, an important objective for central banks, as we have seen above.

\section{IMPLICATIONS FOR THE ROLE OF A CENTRAL BANK}

Armed with these seven guiding principles, we can now look at what institutional features a central bank should have in conducting its operations. We derive the following implications/criteria for the role of a central bank:

- Price stability should be the overriding, longrun goal of monetary policy;

- An explicit nominal anchor should be adopted;

- A central bank should be goal dependent;

- A central bank should be instrument independent;

- A central bank should be accountable;

- A central bank should stress transparency and communication;

- A central bank should also have the goal of financial stability.

\section{Price Stability Should Be the Overriding, Long-Run Goal of Monetary Policy}

Together, the first three principles for monetary policy outlined above suggest that the overriding, long-run goal of monetary policy should be price stability. A goal of price stability immediately follows from the benefits of low and stable inflation, which promote higher economic output. Furthermore, an institutional commitment to price stability is one way to make time-inconsistency of monetary policy less likely. An institutional commitment to the price stability goal provides a counter to timeinconsistency because it makes it clear that the central bank must focus on the long-run and thus resist the temptation to pursue short-run expansionary policies that are inconsistent with the long-run, price stability goal.

The third principle, that fiscal policy should be aligned with monetary policy, provides another reason why price stability should be the overriding, long-run goal of monetary policy. As McCallum (1990) has pointed out, "unpleasant monetarist arithmetic" only arises if the fiscal authorities are the first mover. In other words, if the fiscal authorities are the dominant player and can move first- 
thus setting fiscal policy exogenously, knowing that the monetary authorities will be forced to accommodate their policies to maintain the longrun government budget constraint-then fiscal policy will determine the inflation rate. Indeed, this is the essence of the fiscal theory of the price level. On the other hand, as McCallum (1990) points out, if the monetary authorities are the dominant player and move first, then it will be fiscal policy that will accommodate in order to satisfy the long-run government budget constraint and monetary policy will determine the inflation rate. An institutional commitment to price stability as the overriding, long-run goal, is just one way to ensure that monetary policy moves first and dominates, forcing fiscal policy to align with monetary policy.

The sixth guiding principle, that output fluctuations should also be a concern of monetary policy, suggests that a fanatic pursuit of price stability could be problematic because policymakers should see not only price fluctuations, but also output fluctuations as undesirable. This is why the price stability goal should be seen as overriding in the long-run but not in the short-run. As Lars Svensson (1999) states, central banks should pursue what he calls "flexible inflation targeting," in which the speed at which a central bank tries to get to price stability reflects their concerns about output fluctuations. The more heavily a central bank cares about output fluctuations, the more time it should take to return to price stability when it is not already there. However, because a "flexible inflation targeter" always sets a long-term price stability goal for inflation, the fact that a central bank cares about output fluctuations is entirely consistent with price stability as the long-run, overriding goal.

\section{An Explicit Nominal Anchor Should Be Adopted}

Although an institutional commitment to price stability helps solve time-inconsistency and fiscal alignment problems, it does not go far enough because price stability is not a clearly defined concept. Typical definitions of price stability have many elements in common with the commonly used legal definition of pornography in the United Statesyou know it when you see it. Thus, constraints on fiscal policy and discretionary monetary policy to avoid inflation might end up being quite weak because not everyone will agree on what price sta- bility means in practice, providing both monetary policymakers and politicians a loophole to avoid making tough decisions to keep inflation under control. A solution to this problem, which supports the first three guiding principles, is to adopt an explicit nominal anchor that ties down exactly what the commitment to price stability means.

There are several forms that an explicit nominal anchor can take. One is a commitment to a fixed exchange rate. For example, in 1991, Argentina established a currency board that required the central bank to exchange U.S. dollars for new pesos at a fixed exchange rate of one to one. A second nominal anchor is for the central bank to have a money-growth target, as was the case in Germany. A third nominal anchor is for there to be an explicit numerical inflation goal as in inflation-targeting countries such as New Zealand, Canada, the United Kingdom, Australia, and Brazil, among others. All these forms of explicit nominal anchors can help reduce the time-inconsistency problem, as the success of countries using them in lowering and controlling inflation demonstrates (Mishkin, 1999b). These nominal anchors also help restrain fiscal policy and also are seen as an important benefit of inflation targeting in countries such as New Zealand and Canada (Mishkin and Posen, 1997, and Bernanke, Laubach, Mishkin, and Posen, 1999).

One criticism of adopting an explicit nominal anchor, such as an inflation target, is that it will necessarily result in too little emphasis on reducing output fluctuations, which is inconsistent with the guiding principle that monetary policy should be concerned with output as well as price fluctuations. However, this view is mistaken. Inflation targeting, as it has actually been practiced (Mishkin and Posen, 1997, and Bernanke, Laubach, Mishkin, and Posen, 1999), has been quite flexible and has not led to larger output fluctuations. Indeed, adoption of an inflation target can actually make it easier for central banks to deal with negative shocks to the aggregate economy. Because a decline in aggregate demand also leads to lower-than-expected inflation, a central bank is able to respond with a monetary easing, without causing the public to question its anti-inflationary resolve. Furthermore, inflation targeting can make it less likely that deflation, a fall in the price level, would occur. There are particularly valid reasons for fearing deflation in today's world, including the possibility that it might promote financial instability and precipitate a severe economic contraction. Indeed, deflation 
has been associated with deep recessions or even depressions, as in the 1930s, and the recent deflation in Japan has been one factor that has weakened the financial system and the economy. Targeting inflation rates of above zero, as all inflation targeters have done, makes periods of deflation less likely. The evidence on inflation expectations from surveys and interest rate levels suggest that maintaining a target for inflation above zero (but not too far above) for an extended period does not lead to instability in inflation expectations or to a decline in the central bank's credibility.

\section{Central Banks Should Be Goal Dependent}

Although there is a strong rationale for the price stability goal and an explicit nominal anchor, who should make the institutional commitment? Should the central bank independently announce its commitment to the price stability goal or would it be better to have this commitment be mandated by the government?

Here the distinction between goal independence and instrument independence made by Debelle and Fischer (1994) and Fischer (1994) is quite useful. Goal independence is the ability of the central bank to set its own goals for monetary policy, while instrument independence is the ability of the central bank to independently set the instruments of monetary policy to achieve the goals. The fifth guiding principle that the public must be able to exercise control over government actions and that policymakers must be accountable, so basic to democracy, strongly suggests that the goals of monetary policy should be set by the elected government. In other words, a central bank should not be goal independent. The corollary of this view is that the institutional commitment to price stability should come from the government in the form of an explicit, legislated mandate for the central bank to pursue price stability as its overriding, long-run goal.

Not only is the prinicple of a legislated mandate and goal dependence of the central bank consistent with basic principles of democracy, but it has the further advantage that it is consistent with the second and third guiding principles - it makes timeinconsistency less likely, while making alignment of fiscal policy with monetary policy more likely. As we discussed above, the source of the time-inconsistency problem is more likely to be embedded in the political process than it is in the central bank. Once politicians commit to the price stability goal by passing central bank legislation with a price stability mandate, it becomes harder for them to put pressure on the central bank to pursue short-run expansionary policies that are inconsistent with the price stability goal. Furthermore, a government commitment to price stability also is a commitment to making monetary policy dominant over fiscal policy, ensuring a better alignment of fiscal policy with monetary policy.

An alternative way to solve time-inconsistency problems has been suggested by Rogoff (1985): Grant both goal and instrument independence to a central bank and then appoint conservative central bankers to run it, who put more weight on controlling inflation (relative to output) than does the general public. The result will be low inflation, but at the cost of higher output variability than the public desires.

There are two problems with this solution. First, having "conservative" central bankers impose different preferences from those of the public on the conduct of monetary policy is inherently undemocratic. Basic democratic principles indicate that the preferences of policymaking should be aligned with those of the society at large. Second, in the long run, a central bank cannot operate without the support of the public. If the central bank is seen to be pursuing goals that are not what the public wants, support for central bank independence is likely to erode. Thus appointment of "conservative" central bankers may not be stable in the long run and will not provide a permanent solution to the timeinconsistency problem.

The same principles that suggest that the central bank should be goal dependent, with the commitment to the price stability goal mandated by the government, also suggest that the commitment to an explicit nominal anchor should be made by the government. In the case of an exchange-rate target, the government should set the target, as in Argentina, or in the case of an inflation target, the government should set the numerical inflation goal. The fact that the government sets these targets so that the central bank is goal dependent does not mean that the central bank should be cut out of the decision-making process. Because the central bank has both prestige and expertise in the conduct of monetary policy, governments will almost always be better served by setting these targets in consultation with the central bank.

Although it is clear that the government should set the goal for the explicit nominal anchor in the long-run, it is more controversial whether it should 
set it in the short-run or intermediate-run. If a government, for example, set a short-run inflation or exchange rate target that was changed every month or every quarter, this could easily lead to time inconsistency in which short-run objectives would dominate. In many countries that target inflation, the Ministry of Finance, as the representative of the government, does set an annual inflation target; however, as documented in Bernanke, Laubach, Mishkin, and Posen (1999), the target rarely is changed once price stability is achieved. Thus, even though (in theory) governments could manipulate an annual inflation target to pursue short-run objectives, the transparency of goal-setting leads to a long-run approach to setting inflation targets even when it is done on an annual basis. The situation for the United States is even more complicated. Because of our congressional system, the Treasury Secretary is not the representative of Congress, in contrast to the Minister of Finance who does represent parliament in a parliamentary system. Instead the Treasury Secretary represents the executive branch. Thus, who represents the American government in setting a short- or intermediate-term target for monetary policy is not clear cut. This problem is not as severe for setting the long-run goal of monetary policy, which could be done by a congressional commission with representatives from both the executive and legislative branches, as well as from the public and the central bank. However, the difficulties of delegating the setting of shorter run targets for monetary policy in a congressional system may require that the central bank keep this responsibility. ${ }^{5}$

\section{Central Banks Should Be Instrument Independent}

Although the arguments above suggest that central banks should be goal dependent, the guiding principles in the previous section provide a strong case that central banks should be instrument independent. Allowing central banks to control the setting of monetary policy instruments provides additional insulation from political pressures to exploit short-run tradeoffs between employment and inflation. Instrument independence means that the central bank is better able to avoid the pursuit of time-inconsistent policies in line with the third guiding principle.

The fourth guiding principle, that monetary policy needs to be forward looking in order to take account of the long lags in the effect of monetary policy on inflation, provides another rationale for instrument independence. Instrument independence insulates the central bank from the myopia that is frequently a feature of the political process arising from politicians' concerns about getting elected in the near future. Thus, instrument independence makes it more likely that the central bank will be forward looking and adequately allow for the long lags from monetary policy actions to inflation in setting their policy instruments.

Recent evidence seems to support the conjecture that macroeconomic performance is improved when central banks are more independent. When central banks in industrialized countries are ranked from least legally independent to most legally independent, the inflation performance is found to be the best for countries with the most independent central banks (see Alesina and Summers, 1993, Cukierman, 1992, and Fischer, 1994, among others). However, there is some question whether causality runs from central bank independence to low inflation or, rather, whether a third factor is involved, such as the general public's preferences for low inflation that create both central bank independence and low inflation (Posen, 1995).

The bottom line is that basic principles for monetary policy and democracy suggest that central banks should have instrument but not goal independence. This degree of independence for central banks is analogous to the relationship between the U.S. military and the government during the successfully prosecuted Gulf War in 1991. The military had instrument independence: It had complete control over the prosecution of the war with little interference from the government (in contrast to the less successfully waged Vietnam War). On the other hand, the military did not have goal independence: It was the Commander in Chief, George Bush, who made the decisions as to what the objectives and goals of the war would be.

\section{Central Banks Should Be Accountable}

The fifth guiding principle, that policymakers should be accountable, indicates that the central bank should be subject to government and public scrutiny. One way of ensuring accountability is to make the independence of the central bank subject to legislative change by allowing the act that creat-

\footnotetext{
${ }^{5}$ For further discussion of who should set an inflation target in the United States, see Bernanke, Laubach, Mishkin, and Posen (1999).
} 
ed the central bank to be modified by legislation at any time. Another way is to mandate periodic reporting requirements to the government, for example, as was done in the Humphrey-Hawkins legislation which requires the Chairman of the Federal Reserve to testify to Congress twice a year.

The need for central banks to be accountable provides an additional reason why central banks should have an explicit nominal anchor. If there is no explicit nominal anchor, it is far less clear upon what criterion the central bank should be judged, and thus it is harder to hold it accountable. On the other hand, with an explicit nominal anchor, like a target for inflation or the exchange rate, the public and the politicians have a clear cut benchmark to assess the performance of the central bank. Thus, an explicit nominal anchor enhances the accountability of the central bank. Indeed, with an explicit nominal anchor, accountability can be enforced by making the central bank governor subject to dismissal if he or she breaches the goals set by the government, as is the case in New Zealand.

\section{Central Banks Should Stress Transparency and Communication}

Increased transparency of monetary policymaking is another important way to increase central bank accountability in line with the fifth guiding principle. Central banks need to communicate clearly their monetary policy strategy in order to explain their objectives and how they plan to achieve them. Each time they change their policy instruments, such as the interbank interest rate, they also need to clearly state the decision and then explain the rationale for it. Transparency can be further increased by publication of the central bank's forecast and the minutes of the discussion of monetary policy.

In addition, central banks need to pursue many outreach vehicles to communicate with the public. These include the continual making of speeches to all elements of society, more openness with the press and media, and the development of brochures and reports that are accessible to the public. Particularly noteworthy in this regard are the "Inflation Report" type documents initially developed by the Bank of England and now emulated by many other central banks. These documents depart from the usual dull-looking, formal reports of central banks to take on the best elements of textbook writing (fancy graphics, use of boxes) in order to better communicate with the public.

Increasing transparency and accountability not only helps to align central banks with democratic principles, and is thus worthy of its own right, but it also has benefits for the ability of central banks to conduct monetary policy successfully. Transparency reduces the uncertainty about monetary policy, interest rates, and inflation, thus making private-sector planning easier. Transparency and communication also promote a better public understanding of what central banks can do-promote price stability which, as suggested by the first guiding principle, has the potential to enhance economic growth in the long run-and what central banks cannot do-create permanent increases in output and employment through expansionary policy. Better public understanding of what central banks can and cannot do is then likely to help generate more public support for monetary policy, which is focused on price stability, becoming the long-run, overriding goal.

Although central bankers find their life to be a more comfortable one when they are not accountable and can avoid intense public scrutiny, increased transparency and accountability have important benefits for central bankers, helping them to adhere to the first five guiding principles outlined in the previous section. Because transparency and accountability can increase the public support for the price stability goal and longer-term thinking on the part of the central bank, they can reduce political pressures on the central bank to pursue inflationary monetary policy and, thus, limit the timeinconsistency problem, while generating more support for forward-looking policy by the central bank. Also, greater transparency and communication can help the central bank convince the public that fiscal policy needs to be aligned with monetary policy.

In addition, transparency and accountability can increase support for independence of the central bank. $^{6}$ An instructive example is provided by the granting of instrument independence to the Bank of England in May 1997. Prior to this date, monetarypolicy decisions in the United Kingdom were made by the government (the Chancellor of the Exchequer) rather than by the Bank of England. When, on May 6, 1997, the Chancellor of the Exchequer, Gordon Brown, announced the granting of instrument independence to the Bank of England, giving it the power to set the overnight interest rate, he made it

\footnotetext{
${ }^{6}$ Blinder (1998) also makes a strong case for increased transparency and accountability of central banks.
} 
particularly clear at the press conference that, in his view, the action had been made possible by the increased transparency and accountability of policy under the recently adopted inflation-targeting regime.

\section{Central Banks Should also Have a Financial Stability Goal}

Because central banks should care about output fluctuations (Principle 6) and the most serious economic contractions arise when there is financial instability (Principle 7), central banks also need to focus on preventing financial instability. The primary way that central banks prevent financial instability is by acting as a lender of last resort, that is, by supplying liquidity to the financial system to keep a financial crisis from spinning out of control. Because acting as a lender of last resort, in effect, provides a safety net for financial institutions to whom the funds will be channeled, it creates a moral hazard problem in which these institutions who are potential borrowers have incentives to take on excessive risk, which can make financial instability more likely. Thus, central banks need to consider the tradeoff between the moral hazard cost of the role as lender of last resort and the benefit of preventing financial crises. Keeping moral hazard from getting out of hand indicates that central banks should not perform the role of lender of last resort unless it is absolutely necessary; and, therefore, this role should occur very infrequently.

Because lender-of-last-resort lending should be directed at providing funds to solvent, but illiquid, financial institutions and not to insolvent institutions, in order to reduce incentives to take on too much risk by these institutions, the central bank needs to have information regarding to whom it might have to extend loans when it performs this role. One way for the central bank to get this information is for it to have a supervisory role over these institutions. This is an argument for giving central banks a role in prudential supervision (see, e.g., Mishkin, 1992, and Bernanke, 2000). In addition, a supervisory role for the central bank can help it obtain information about whether a situation really is likely to lead to a financial crisis and, thus, requires a lender-oflast-resort intervention. Without this information, the central bank may either intervene too frequently or fail to do so when it is really needed, thus making financial instability more likely. It is possible that central banks can acquire the information they need from supervisory agencies which are separate from the central bank, but some central bank officials doubt this (see Peek, Rosengren, and Tootell, 2000). Thus, there is an argument for the central bank to have a role in prudential supervision, but it is by no means clear cut. Furthermore, there are arguments against central bank involvement in prudential supervision because it may cause a central bank to lose its focus on the price-stability objective.

\section{A FEDERAL RESERVE SCORECARD}

Now that we have outlined what the role of a central bank should be, we can assess how the institutional features of the Federal Reserve measure up. We provide an assessment of whether the way the Fed is set up to conduct its operations is consistent with each of the seven criteria discussed in the previous section.

\section{Price Stability Should Be the Overriding, Long-Run Goal of Monetary Policy}

Through their testimony and speeches, high officials in the Federal Reserve System, and especially Alan Greenspan, have made it quite clear that the overriding, long-run goal for Fed monetary policy is price stability. However, there is no clear mandate from the U.S. government that price stability should be a long-run, overriding goal. The HumphreyHawkins Act passed in 1978, with the revealing title, "Full Employment and Balanced Growth Act," stipulates that monetary policy should have goals of full employment and economic growth, as well as price stability. It is true that the HumphreyHawkins Act could be interpreted as allowing for price stability to be the overriding, long-run goal because, as was indicated previously, price stability is a means of promoting high economic growth and full employment in the long-run. However, it is even easier to interpret the legislation as supporting an emphasis on pursuit of full employment and economic growth in the short-run, which is inconsistent with the pursuit of price stability. The lack of a clear mandate for price stability can lead to the time-inconsistency problem in which political pressure is put on the Fed to engage in expansionary policy to pursue short-run goals.

In contrast to the United States, many other countries now have legislation which mandates price stability as the overriding, long-run goal of monetary policy, and this is a growing trend. For example, a mandate for price stability as the overriding, long-run goal for monetary policy was a 
requirement for entry into the European Monetary Union, and the Maastricht Treaty gives this mandate to the central banking system for the European Monetary Union, which most accurately referred to as the Eurosystem. ${ }^{7}$ This trend also has been evident even in emerging market countries, where many central banks have had their mandate revised to focus on price stability.

On the first criterion of the need for an institutional commitment to price stability, as the overriding long-run goal, the United States does not score well.

\section{An Explicit Nominal Anchor Should Be Adopted}

Not only has the U.S. government not committed to price stability as the overriding, long-run goal, but also neither it nor the Fed has adopted an explicit nominal anchor. The actions and rhetoric of the Greenspan Fed have made it clear that it will fight to keep inflation from rising from the current level of around 2 percent, and it is fair to characterize the Fed as having an implicit nominal anchor. Nonetheless, the Federal Reserve has not come out and articulated an explicit goal for inflation and has, instead, stated its commitment to price stability. This has been loosely defined by Alan Greenspan as a situation in which changes in the price level are not a major consideration for businesses and households. At the present time, the public (and maybe even members of the FOMC) have no idea of whether the Fed's goal for inflation is 1 percent, 2 percent, or possibly higher. I think it is fair to say that right now the nominal anchor in the United States is Alan Greenspan. The problem is that this leaves some ambiguity as to what the Fed's target is. Even more importantly, the existence of this implicit nominal anchor depends on personalities. Alan Greenspan, despite his recent reappointment, will not be around forever. When he steps down, will the public believe that there is sufficient commitment to a nominal anchor to keep inflation from appearing again?

On the criterion of having an explicit nominal anchor, the institutional set up of the Fed also does not score well.

\section{Central Banks Should Be Instrument Independent}

The Federal Reserve has been set up to be far more independent than other government agencies in the United States. Members of the Board of Governors are appointed by the government for 14- year terms, insulating them from political pressure, while Reserve Bank presidents, who also sit on the FOMC, are appointed by the boards of directors at each Reserve Bank and are not subject to Congressional review. Even more important is that the Federal Reserve generates substantial profits, on the order of $\$ 20$ billion per year, most of which it returns to the U.S. Treasury, so that it has its own revenue base and is not dependent on funds from the government. Indeed, by law the Federal Reserve is exempt from General Acounting Office (GAO) audits of deliberations, decisions, or actions on monetary policy matters.

Given its insulation from the political process and its financial independence, it should be no surprise that the Fed has complete control over setting its monetary policy instruments. This has the benefits of enabling the Fed to resist political pressure to engage in time-inconsistent expansionary policy and to be forward-looking in the setting of its policy instruments.

On the criteria of instrument independence the Fed scores well.

\section{Central Banks Should Be Goal Dependent}

We have already seen that independence can go too far. Instrument independence is desirable but goal independence is problematic. The independence of the Fed-described above-and the lack of a clear mandate from the government allows the Fed to make the decisions on what the goals of its policies should be. Thus the Fed has a high degree of goal independence. In some ways goal independence makes the Fed's job easier because it insulates it from political pressure, but it does have a downside. The substantial goal independence of the Federal Reserve creates a fair amount of tension in a democratic society because it allows an elite group to set the goals of monetary policy. Indeed, recent criticism of the Federal Reserve may have been prompted by the impression that the Federal Reserve, and particularly its Chairman, has become too powerful.

The goal independence of the Federal Reserve should not be seen as total, however. Politicians do have the ability to influence the goals of the Fed because the Congress can modify the Federal Reserve

\footnotetext{
${ }^{7}$ The Eurosystem currently is made up of the eleven national central banks of the countries that have joined EMU, with the European Central Bank (ECB) at the center having a role similar to that of the Board of Governors in the Federal Reserve System.
} 
Act at any time. Also, the Fed has a great interest in other legislation that affects its operations. A case in point is the recent Gramm-Bliley-Leach Financial Services Modernization Act, passed in 1999, which had major implications for whether the Federal Reserve would continue to have supervisory responsibilities over large banking organizations (which it continued to keep). Furthermore, Congress can criticize the budget of the Fed for items that are unrelated to monetary policy or foreign-exchange operations. As an example, in 1996 Senators Dorgan and Reid called for Congress to exercise budgetary authority over the nonmonetary activities of the Federal Reserve because they were concerned that the Fed was too focused on fighting inflation and not enough on reducing unemployment.

As a comparison, the Eurosystem should be seen in some ways as more goal independent than the Federal Reserve System and in other ways less. The Maastricht Treaty specifies that the overriding, long-run goal of the ECB is price stability, so that the goal for the Eurosystem is more clearly specified than it is for the Federal Reserve System. However, Maastricht did not specify exactly what this price stability means so the Eurosystem has defined the quantitative goal for monetary policy, an inflation rate between 0 and 2 percent. From this perspective, the Federal Reserve System is slightly less goal dependent than the Eurosystem. On the other hand, the Eurosystem's statutes cannot be changed by legislation, but only by alterations to the Maastricht Treaty. From this perspective, the Eurosystem is much less goal dependent than the Federal Reserve System because its statutes are specified in a treaty and thus are far harder to change than statutes that are embedded in legislation.

As the examples above indicate, the Federal Reserve is not goal dependent, but we should not take this view too far. Thus, on the goal dependence criteria, the Fed's score is mixed.

\section{Central Banks Should Be Accountable}

Closely related to goal dependence is the accountability of the central bank to meet its goals. There are formal accountability mechanisms for the Fed. For example, the Chairman of the Board of Governors has been required to testify twice a year to Congress about the conduct of monetary policy under the Humphrey-Hawkins legislation. Also, as we have seen, the Fed is subject to punitive actions by the Congress if it so chooses, either by amending the Federal Reserve Act or through passage of other legislation that affects the Fed.

On these grounds the Federal Reserve System is more accountable than the Eurosystem. As we have seen, the Eurosystem's statutes cannot be modified by legislation but, rather, requires amendment to a treaty, a far more difficult process. Moreover, although the President of the European Central Bank is required to testify once a year to the European Parliament, this requirement may not guarantee sufficient oversight of the Eurosystem's policies. Since the European Parliament is currently significantly less powerful than the national parliaments of the countries that make up the Monetary Union, scrutiny by that organization would not influence the Eurosystem's behavior as strongly as would oversight by a more powerful body, such as a consortium of national parliaments or the individual parliaments themselves. It is not clear to whom the Eurosystem would be accountable.

However, the absence of an explicit nominal anchor means that there is no benchmark against which the public or Congress can measure the performance of the Federal Reserve System. In contrast, the Eurosystem has outlined its price-stability goal of inflation between 0 and 2 percent, so there is a predetermined criterion to judge its performance. Thus, despite the requirement that the Fed testify to Congress, the accountability of the Fed is not very strong. The Federal Reserve is able to obscure what its strategy and goals are and has indeed done this in the past. This leaves open the possibility that there could be a political backlash against a "high-handed" Federal Reserve that could have adverse consequences on its independence and ability to successfully conduct monetary policy in the future.

On the accountability criteria, the Fed also does not score very well.

\section{Central Banks Should Stress Transparency and Communication}

In recent years, the Fed has come a long way on the transparency and communication front. In the past, the Fed had a reputation for not only being unclear about its goals and strategy, but for keeping markets in the dark about its setting of policy instruments. This has changed dramatically in recent years. Starting in 1994, the Fed began to announce its policy actions after every FOMC meeting. It then moved in 1999 to announcing the bias in the direc- 
tion of future moves in the federal funds rate, which caused some confusion, and so replaced this announcement at the beginning of this year with one that indicates the balance of risks for the futurewhether toward higher inflation or toward a weaker economy. Fed officials also have been more active in articulating the strategy of monetary policy, its need to be preemptive, and the importance of the pursuit of price stability.

Despite improved transparency and communication, the lack of explicit goals has meant that Fed transparency is still much less than at many other central banks. In contrast to central banks that have adopted inflation targeting, the Fed produces nothing like an "Inflation Report" in which it clearly lays out in plain English the strategy for monetary policy and how well the central bank has been doing. One consequence of the weakness of Fed transparency and communication is that the public debate on monetary policy in the United States still has a tendency to focus on short-run considerations, as reflected in politicians' focus on “jobs, jobs, jobs" when discussing monetary policy. This focus on short-run considerations is substantially less in countries where central banks use communication vehicles such as "Inflation Reports" to refocus the public debate on longer-run considerations such as price stability.

It is interesting to contrast the way public debate is conducted with what has occurred in Canada, which has adopted an inflation-targeting regime with high transparency and accountability. In 1996, the president of the Canadian Economic Association made a speech criticizing the Bank of Canada for pursuing monetary policy that (he claimed) was too contractionary. His speech sparked off a widespread public debate. Instead of degenerating into calls for the immediate expansion of monetary policy with little reference to the long-run consequences of such a policy change, the debate was channeled into a substantive discussion over what should be the appropriate target for inflation, with both the Bank and its critics obliged to make explicit their assumptions and estimates of the costs and benefits of different levels of inflation. Indeed, the debate and the Bank of Canada's record and responsiveness led to increased support for the Bank of Canada, with the result that criticism of the Bank and its conduct of monetary policy was not a major issue in the 1997 elections as it had been during the 1993 elections.

On the transparency and communication crite- ria, the Fed's score is mixed, although it has been improving over time.

\section{Central Banks Should also Have a Financial Stability Goal}

Here the Fed's performance has been very strong. The Greenspan Fed has made it very clear that it will act decisively to prevent financial crises and has done so not only with words but with actions. The Fed's actions immediately after the October 19, 1987, stock market crash are a textbook case of how a lender-of-last-resort role can be performed brilliantly. ${ }^{8}$ The Fed's action was immediate, with Greenspan announcing right before the market opened on October 20 of the Federal Reserve System's "readiness to serve as a source of liquidity to support the economic and financial system," which operated to decrease uncertainty in the marketplace. Reserves were injected into the system, but once the crisis was over, they were withdrawn. Not only was a crisis averted so that the business cycle expansion continued, but also the inflationary consequences of this exercise of the lender-of-last-resort role were small. The 75 basis point decrease in the federal funds rate in the Fall of 1998 immediately after the Russian financial crisis and the near-failure of Long-Term Capital Management, which roiled U.S. capital markets, also illustrated the Fed's commitment to act decisively to prevent financial instability. The aftermath was an economy that continued to expand, with inflation staying at the 2 percent level.

On the criteria of the commitment to the financial stability goal, the Fed's score is excellent.

\section{CONCLUSION: WHAT SHOULD THE FED DO?}

Our scorecard for the Fed indicates that although the institutional set up of the Fed scores well on some criteria, there is room for improvement in others. But, is there a need for the Fed as an institution to change? The Fed's performance in recent years has been extraordinary. It has been able to bring down inflation in the United States to the 2 percent level, which can reasonably be characterized as being consistent with price stability, while the economy has been experiencing the longest business cycle expansion in U.S. history, with very

\footnotetext{
${ }^{8}$ Indeed, this example appears in my textbook (Mishkin, 1998).
} 
high rates of economic growth. As my son likes to say, "It don't get no better than this." The natural question then arises: If it ain't broke, why fix it?

However, our Fed scorecard suggests that we do need to consider institutional improvements in the way the central bank operates. The absence of an institutional commitment to price stability, along with weak Fed transparency, which stems from the absence of an explicit nominal anchor, leaves the Fed open to political pressure to pursue short-run objectives (i.e., job creation). This might lead to timeinconsistent expansionary policy and would produce inflation. In the past, after a successful period of low inflation, the Federal Reserve has "fallen off the wagon" and reverted to inflationary monetary policy - the 1970s are one example - and, without an explicit nominal anchor, this could certainly happen again in the future.

Indeed, the most serious problem with the Fed's institutional framework and the way it currently operates is the strong dependence on the preferences, skills, and trustworthiness of the individuals in charge of the central bank. Yes, the Fed under Alan Greenspan has been doing a great job, and so the Fed's prestige and credibility with the public have risen accordingly. But the Fed's leadership will eventually change, and there is no guarantee that the new leadership will be committed to the same approach. Nor is there any guarantee that the relatively good working relationship that now exists between the Fed and the executive branch will continue. In a different economic or political environment-and considering the possibility for a backlash against the Fed's lack of accountabilitythe Fed might face far stronger attacks on its independence and increased pressure to engage in over-expansionary policies, further raising the possibility that inflation will shoot up again.

So what should the Fed do? The answer is that the Fed should continue in the direction that it has already begun to increase its transparency and accountability. First, it should advocate a change in its mandate to put price stability as the overriding, long-run goal of monetary policy. Second, it should advocate that the price-stability goal should be made explicit, with a numerical long-run inflation goal. Government involvement in setting this explicit goal would be highly desirable, making the Fed goal independent, which should help retain public support for the Fed's instrument independence. Third, the Fed should produce an "Inflation Report" type of document that clearly explains its strategy for monetary policy and how well it has been doing in achieving its announced inflation goal.

The outcome of these changes is that the Fed would be moving to an inflation-targeting regime of the type described in our book, which has been recently published by the Princeton University Press (Bernanke, Laubach, Mishkin, and Posen, 1999). Clearly, the U.S. Congress and executive branch need to play an important role in encouraging the Fed to move toward inflation targeting. A detailed outline of a proposal for how this might be done can be found in our book. I leave you to read it on your own. Otherwise, you will be subjected to another full lecture.

\section{REFERENCES}

Alesina, Alberto, and Lawrence H. Summers. "Central Bank Independence and Macroeconomic Performance: Some Comparative Evidence," Journal of Money, Credit, and Banking (May 1993), pp. 151-62.

Andersen, Palle, and David Gruen. "Macroeconomic Policies and Growth," in Productivity and Growth, Palle Andersen, Jacqueline Dwyer, and David Gruen, eds., Reserve Bank of Australia, 1995, pp. 279-319.

Barro, Robert J., and David Gordon. "A Positive Theory of Monetary Policy in a Natural Rate Model," Journal of Political Economy (August 1983), pp. 589-610.

Bernanke, Ben S. "Non-Monetary Effects of the Financial Crisis in the Propagation of the Great Depression," American Economic Review (March 1983), pp. 257-76.

"Comment on 'The Synergies Between Bank Supervision and Monetary Policy: Implications for the Design of Bank Regulatory Structure,," in Prudential Supervision: What Works and What Doesn't, Frederic S. Mishkin, ed., University of Chicago Press, forthcoming.

, Thomas Laubach, Frederic S. Mishkin, and Adam S. Posen. Inflation Targeting: Lessons from the International Experience, Princeton University Press, 1999.

Blinder, Alan S. Central Banking in Theory and Practice, MIT Press, 1998.

Briault, Clive. "The Costs of Inflation," Bank of England Quarterly Bulletin (February 1995), pp. 33-45.

Calvo, Guillermo. "On the Time Consistency of Optimal Policy in the Monetary Economy," Econometrica (November 1978), pp. 1411-28.

Corsetti, Giorgio, Paolo Pesenti, and Noriel Roubini. "What Caused the Asian Currency and Financial Crisis? Part I and II," NBER Working Papers, nos. 6833 and 6834, 1998. 
Cukierman, Alex. Central Bank Strategy, Credibility, and Independence: Theory and Evidence, MIT Press, 1992.

Debelle, Guy, and Stanley Fischer. "How Independent Should a Central Bank Be?" in Goals, Guidelines, and Constraints Facing Monetary Policymakers, Jeffrey C. Fuhrer, ed., Federal Reserve Bank of Boston, 1994, pp. 195-221.

English, William B. "Inflation and Financial Sector Size," Finance and Economics Discussion Series No. 96-16, Board of Governors of the Federal Reserve System, April 1996.

Feldstein, Martin. "Capital Income Taxes and the Benefits of Price Stabilization,” NBER Working Paper 6200, September 1997.

Fischer, Stanley. "Modern Central Banking," in The Future of Central Banking, Forrest Capie, Charles A. E. Goodhart, Stanley Fischer, and Norbert Schnadt, eds., Cambridge University Press, 1994, pp. 262-308.

Friedman, Milton, and Anna J. Schwartz. A Monetary History of the United States, 1867-1960, Princeton University Press, 1963.

King, Mervyn, "Changes in UK Monetary Policy: Rules and Discretion in Practice," Journal of Monetary Economics, (June 1997), pp. 81-97.

Kydland, Finn, and Edward Prescott. "Rules Rather than Discretion: The Inconsistency of Optimal Plans," Journal of Political Economy (June 1977), pp. 473-91.

McCallum, Bennett T. "Inflation: Theory and Evidence," in Handbook of Monetary Economics, Ben M. Friedman and Frank H. Hahn, eds., Elsevier Press, 1990, pp. 963-1012.

"Two Fallacies Concerning Central-Bank Independence," American Economic Review (May 1995), pp. 207-11.

Mishkin, Frederic S. "Asymmetric Information and Financial Crises: A Historical Perspective," in Financial Markets and Financial Crises, R. Glenn Hubbard, ed., University of Chicago Press, 1991, pp. 69-108.

"An Evaluation of the Treasury Plan for Banking Reform," Journal of Economic Perspectives (Winter 1992), pp. 133-53.

"Understanding Financial Crises: A Developing Country Perspective," in Annual World Bank Conference on Development Economics, 1996, pp. 29-62.

The Economics of Money, Banking, and Financial Markets, 5th ed., Addison-Wesley Publishing Co., 1998.

"Lessons from the Asian Crisis," Journal of International Money and Finance (August 1999a), pp. 709-23.

"International Experiences with Different Monetary Policy Regimes," Journal of Monetary Economics (June 1999b), pp. 579-605.

and Adam S. Posen. "Inflation Targeting:

Lessons from Four Countries," Economic Policy Review, Federal Reserve Bank of New York (August 1997), pp. 9-110.
Peek, Joe, Eric Rosengren, and Geoffrey Tootell, "The Synergies Between Bank Supervision and Monetary Policy: Implications for the Design of Bank Regulatory Structure," in Prudential Supervision: What Works and What Doesn't, Frederic S. Mishkin, ed., University of Chicago Press, forthcoming.

Posen, Adam S. "Declarations Are Not Enough: Financial Sector Sources of Central Bank Independence," in NBER Macroeconomics Annual, Ben S. Bernanke and Julio J. Rotemberg, eds., MIT Press, 1995, pp. 253-74.

Rogoff, Kenneth. "The Optimal Degree of Commitment to an Intermediate Monetary Target," Quarterly Journal of Economics (November 1985), pp. 1169-89.

Sargent, Thomas, and Neil Wallace. "Some Unpleasant Monetarist Arithmetic," Quarterly Review, Federal Reserve Bank of Minneapolis (Fall 1981), pp. 1-17.

Svensson, Lars. "Inflation Targeting as Monetary Policy Rule," Journal of Monetary Economics (June 1999), pp. 607-54.

Taylor, John, ed. Monetary Policy Rules, University of Chicago Press, Chicago, 1999.

Woodford, Michael. "Monetary Policy and Price Level Determinacy in a Cash-in-Advance Economy," Economic Theory, vol. 4, no. 3 (1994), pp. 345-80.

"Price-Level Determinacy with Control of a Monetary Aggregate," Carnegie-Rochester Conference Series on Public Policy (December 1995), pp. 1-46. 
RE V I E W

14 november/december 2000 